\title{
Desmosomal Molecules In and Out of Adhering Junctions: Normal and Diseased States of Epidermal, Cardiac and Mesenchymally Derived Cells
}

\author{
Sebastian Pieperhoff,, ${ }^{1,2}$ Mareike Barth, ${ }^{1}$ Steffen Rickelt, ${ }^{1}$ and Werner W. Franke ${ }^{1,3}$ \\ ${ }^{1}$ Helmholtz Group for Cell Biology, German Cancer Research Center, Im Neuenheimer Feld 581, 69120 Heidelberg, Germany \\ ${ }^{2}$ Department of Zoology and Faculty of Land and Food Systems, University of British Columbia, 2357 Main Mall, \\ Vancouver, BC, Canada V6T $1 Z 4$ \\ ${ }^{3}$ Progen Biotechnik GmbH, Maaßstraße 30, 69123 Heidelberg, Germany
}

Correspondence should be addressed to Werner W. Franke, w.franke@dkfz.de

Received 26 February 2010; Accepted 23 March 2010

Academic Editor: Peter J. Koch

Copyright ( $) 2010$ Sebastian Pieperhoff et al. This is an open access article distributed under the Creative Commons Attribution License, which permits unrestricted use, distribution, and reproduction in any medium, provided the original work is properly cited.

Current cell biology textbooks mention only two kinds of cell-to-cell adhering junctions coated with the cytoplasmic plaques: the desmosomes (maculae adhaerentes), anchoring intermediate-sized filaments (IFs), and the actin microfilament-anchoring adherens junctions (AJs), including both punctate (puncta adhaerentia) and elongate (fasciae adhaerentes) structures. In addition, however, a series of other junction types has been identified and characterized which contain desmosomal molecules but do not fit the definition of desmosomes. Of these special cell-cell junctions containing desmosomal glycoproteins or proteins we review the composite junctions (areae compositae) connecting the cardiomyocytes of mature mammalian hearts and their importance in relation to human arrhythmogenic cardiomyopathies. We also emphasize the various plakophilin-2-positive plaques in AJs (coniunctiones adhaerentes) connecting proliferatively active mesenchymally-derived cells, including interstitial cells of the heart and several soft tissue tumor cell types. Moreover, desmoplakin has also been recognized as a constituent of the plaques of the complexus adhaerentes connecting certain lymphatic endothelial cells. Finally, we emphasize the occurrence of the desmosomal transmembrane glycoprotein, desmoglein Dsg2, out of the context of any junction as dispersed cell surface molecules in certain types of melanoma cells and melanocytes. This broadening of our knowledge on the diversity of AJ structures indicates that it may still be too premature to close the textbook chapters on cell-cell junctions.

\section{Introduction}

Typical desmosomes (maculae adhaerentes) are cell-cell junctions connecting cells of epithelial, meningothelial, and myocardial nature or malignantly transformed cells derived therefrom. Over the past two decades the molecular and ultrastructural organization of diverse cell-cell-connecting plasma membrane structures has been elucidated and two novel categories and architectonic principles have been recognized: desmosomal molecules as functionally important components of special non-desmosomal junctions and the existence of certain desmosomal molecules in a nonjunction-bound form.

\section{The Desmosomes of Stratified and Other Epithelia}

The ultrastructural organization and the high lateral packing density of desmosomes in the epidermis or other multistratified vertebrate epithelia is best seen in the electron microscope (e.g., Figure 1), and the corresponding protein compositions of the various desmosomal subtypes in the specific strata have been determined by biochemical analyses and immunolocalization techniques [1-7].

In most stratified epithelia, epidermis included, the desmosome packing density is so high that more than half of the entire cell-cell membrane contact area is represented 


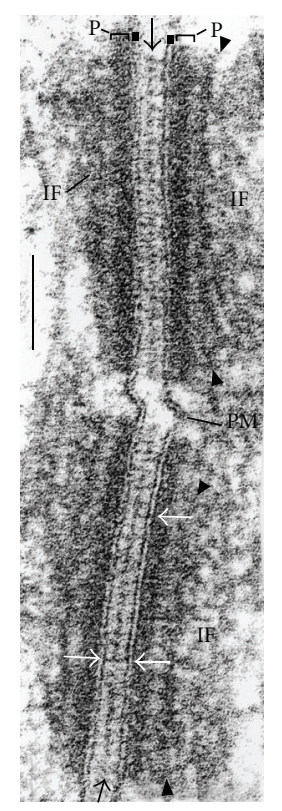

Figure 1: High-magnification electron micrograph of two cross sectioned desmosomal structures connecting stratum spinosum cells of human fetal $(20 \mathrm{wk})$ foot-sole epidermis. Brackets and label "P": cytoplasmic dense plaque; black arrows: midline structure; white arrows: trilaminar "unit membrane" structure of the plasma membrane; arrowheads (top and bottom): secondary dense layer of the plaque; IF: intermediate-sized filaments (for further details see [7]); PM: plasma membrane. Bar: $0.1 \mu \mathrm{m}$.

by desmosomal structures. Using immunohistochemical techniques with desmosomal markers this high packing density is directly demonstrable not only for all layers of the highly cornified mammalian epidermis but also in the skin of lower vertebrates such as fishes and amphibia (Figure 2(a) shows the immunolocalization of plakoglobin on a section of fixed, paraffin-embedded skin of the eel, Anguilla anguilla; Figure 2(b) shows desmoplakin immunostaining on the skin of the frog, Rana pipiens; for details see [8]). Clearly, in stratified epithelia the desmosomal constituents are, together with the keratin filaments, among the most frequent proteins. Moreover, the molecular composition of the epidermal desmosomes - and those of similar multistratified epithelia-has been found to show fundamental strataspecific differences, notably with respect to the desmogleins, Dsg1-4, the desmocollins, Dsc1-3, and the plaque proteins plakophilins, Pkp1-3 (Table 1 and $[4-6,9]$ ).

The stratum-specific molecular ensembles, specifically the Dsg and Dsc glycoproteins, are also of marked importance with respect to the pathogenesis of autoimmune skin diseases of the pemphigus type which show a more or less direct correlation with the specific desmosomal glycoprotein complement of the affected layer (see, e.g., [4, 6, 9, 24$28]$ ). These autoimmune diseases are specifically dealt within other articles of this issue. Another aspect of the desmosomal arrays in the epidermis and other stratified epithelia is their frequent-in some areas almost regular-punctuation by very small "sandwich junctions" (iuncturae structae) con-

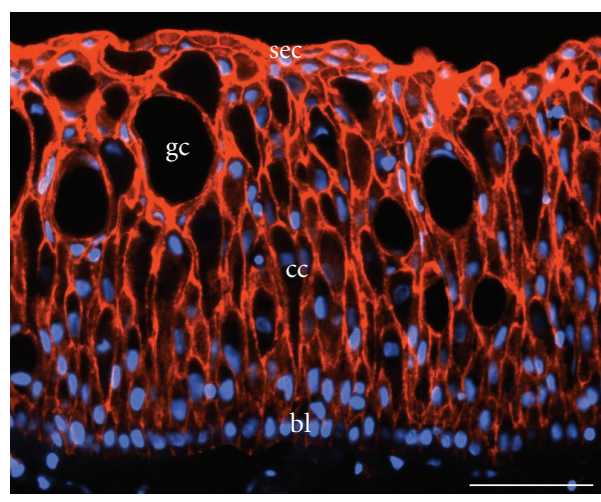

(a)

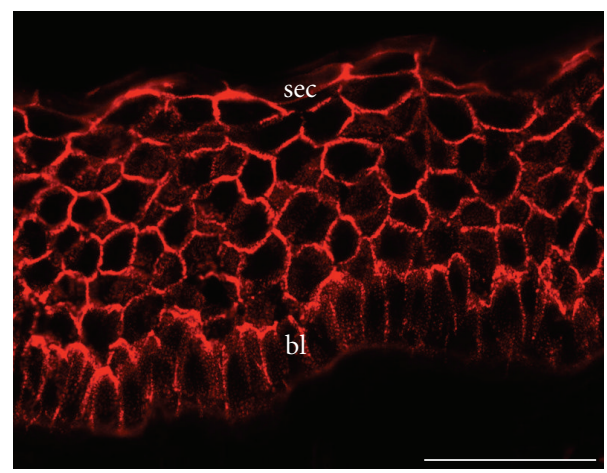

(b)

FIGURE 2: Immunofluorescence microscopy of cryostat sections through fish and amphibian skin, showing the localization of desmosomal components in all layers of the epidermis. (a) Immunofluorescence labeling of plakoglobin (red), in addition to nuclear DAPI staining (blue), in a section through the paraffinembedded skin of an eel (Anguilla anguilla). The section is shown after antigen retrieval and immunoreaction (for methods see [8]) using a monoclonal mouse plakoglobin antibody (mAb PG 5.1; Progen Biotechnik, Heidelberg, Germany). Note the distinct basal layer (stratum basale) of the epidermis and the relatively large club shaped cells ("club cells") as well as the mucous goblet cells and the dense-packed apical cell layers. (b) Immunofluorescence labeling of desmoplakin on a cryostat section through the skin of the frog, Rana pipiens, using mAb DP447 (Progen Biotechnik). Note the continuous pattern of very closely spaced, finely punctate staining of the epidermal desmosomes. Bl: basal layer; cc: club cells; gc: goblet cells; sec: superficial epithelial cells (for histological terminology see [8]). Bar in (a): $100 \mu \mathrm{m}$; bar in (b): $50 \mu \mathrm{m}$.

taining the four times-membrane-spanning tight junction hallmark protein, occludin [29, 30].

\section{The Composite Junctions of the Intercalated Disks (IDs) Connecting Mammalian Cardiomyocytes}

In mammals the development of the ID junctional system connecting cardiomyocytes does not stop at birth but continues postnatally $[15,31,32]$. In particular the two types of adhering junctions originally distinguishable show further polar translocation, accumulation in the ID region 
TABLE 1: Shown are specific cell-cell adhering junctions containing transmembrane glycoproteins and cytoplasmic plaque proteins of "classic" desmosomes and adherens junctions (AJs). Special types of adhering junctions containing desmosomal proteins in human tissues and cell cultures.

\begin{tabular}{|c|c|c|c|c|}
\hline Type & Cells & $\begin{array}{l}\text { Transmembrane } \\
\text { glycoproteins }\end{array}$ & $\begin{array}{l}\text { Some representative } \\
\text { plaque proteins }\end{array}$ & References \\
\hline $\begin{array}{l}\text { Macula adhaerens } \\
\text { (desmosome) }\end{array}$ & $\begin{array}{l}\text { Epithelial and } \\
\text { mesothelial cells and } \\
\text { carcinomas derived } \\
\text { therefrom, } \\
\text { cardiomyocytes of } \\
\text { immature hearts and } \\
\text { cardiac conductive cells }\end{array}$ & $\begin{array}{l}\text { Desmogleins-1-4 } \\
\text { Desmocollins-1-3 }\end{array}$ & $\begin{array}{l}\text { Plakophilins-1-3 } \\
\text { Plakoglobin } \\
\text { Desmoplakin }\end{array}$ & $\begin{array}{l}\text { Franke et al. }[10,11] \\
\text { Cowin et al. }[12] \\
\text { Mertens et al. [13] }\end{array}$ \\
\hline $\begin{array}{l}\text { Area composita } \\
\text { (composite junction) }\end{array}$ & $\begin{array}{l}\text { Cardiomyocytes and } \\
\text { Purkinje fiber cells }\end{array}$ & $\begin{array}{l}\text { N-Cadherin } \\
\text { Cadherin-11 } \\
\text { Desmoglein-2 } \\
\text { Desmocollin-2 }\end{array}$ & $\begin{array}{l}\alpha \text { - and } \beta \text {-Catenin } \\
\text { Proteins p120, p0071 } \\
\text { and } \\
\text { ARVCF } \\
\text { Plakoglobin } \\
\text { Plakophilin-2 } \\
\text { Desmoplakin } \\
\text { Afadin } \\
\text { Myozap }\end{array}$ & $\begin{array}{l}\text { Franke et al. [14] } \\
\text { Pieperhoff and } \\
\text { Franke [15] } \\
\text { Goossens et al. [16] } \\
\text { Seeger et al. [17] }\end{array}$ \\
\hline Complexus adhaerens & $\begin{array}{l}\text { Certain endothelia } \\
\text { (spec. endothelial and } \\
\text { virgultar tissues of } \\
\text { lymph node sinus) }\end{array}$ & $\begin{array}{l}\text { VE-Cadherin } \\
\text { N-Cadherin } \\
\text { Claudin-5 } \\
\text { JAM-A }\end{array}$ & $\begin{array}{l}\alpha \text { - and } \beta \text {-Catenin } \\
\text { Protein p120 } \\
\text { Plakoglobin } \\
\text { Desmoplakin, Afadin }\end{array}$ & $\begin{array}{l}\text { Schmelz and Franke } \\
\text { Hämmerling et al. } \\
\text { [18] } \\
\text { Moll et al. [19] }\end{array}$ \\
\hline Zona limitans externa & Neural retina & N-Cadherin & $\begin{array}{l}\text { Neurojungin } \\
\alpha \text { - and } \beta \text {-Catenin } \\
\text { Plakoglobin } \\
\text { Plakophilin-2 }\end{array}$ & Paffenholz et al. [20] \\
\hline Colligatio permixta & $\begin{array}{l}\text { Astrocytes and } \\
\text { astrocytoma cells }\end{array}$ & $\begin{array}{l}\text { N-Cadherin } \\
\text { Cadherin-11 } \\
\text { VE-Cadherin }\end{array}$ & $\begin{array}{l}\alpha \text { - and } \beta \text {-Catenin } \\
\text { Protein p120 } \\
\text { Plakoglobin } \\
\text { Plakophilin-2 } \\
\text { Afadin }\end{array}$ & $\begin{array}{l}\text { Boda-Heggemann } \\
\text { et al. [21] }\end{array}$ \\
\hline Coniunctio adhaerens & $\begin{array}{l}\text { Mesenchymally derived } \\
\text { cells of high } \\
\text { proliferative activity in } \\
\text { situ and in culture }\end{array}$ & $\begin{array}{l}\text { N-Cadherin } \\
\text { Cadherin-11 }\end{array}$ & $\begin{array}{l}\alpha \text { - and } \beta \text {-Catenin } \\
\text { Proteins p120 and } \\
\text { p0071 } \\
\text { Plakoglobin } \\
\text { Plakophilin-2 } \\
\text { [Plakophilin-3] } \\
\text { Afadin }\end{array}$ & $\begin{array}{l}\text { Rickelt et al. [22] } \\
\text { Barth et al. [23] }\end{array}$ \\
\hline
\end{tabular}

and fusions of the desmosomal and the fascia adhaerens components, accompanied by an increasing amalgamation of the two kinds of molecular ensembles into the new mixed category of area composita (AC) structures (Figures 3(a)$3(\mathrm{c}), 4(\mathrm{~b})$, and 5(a); for details of molecular localizations and biochemical analyses see $[14,15,33]$; for non-mammalian species see however $[8,34])$. As a typical result rather extended AC structures are seen which combine compositional and ultrastructural properties of desmosomes with those of AJs (Figures 3 and 4(b)). In addition, the "mixed AC ensembles" of the ID (Table 1; Figure 4(b)) include a series of additional proteins such as $\alpha$-T-catenin [16] and the recently identified plaque protein called "myozap" [17]. The special organizational importance of certain armadillo-type proteins, in particular plakoglobin and plakophilin-2, for the entire ID contact of cardiomyocytes has also been demonstrated for early stages of murine heart formation in the absence of the genes encoding these proteins $[35,36]$ and in siRNA-downregulation experiments ([3739], for related experiments see also [40, 41]).

The physiological and medical importance of desmosomal molecules in the composite junctions of the myocardiac IDs is most impressively demonstrated by the recent avalanche of publications that specific mutations in genes encoding desmosomal proteins can result in arrhythmogenic cardiomyopathies (ARVC/D), mostly in the right ventricle but left ventricle damages have also been reported (Table 2). Here the gene encoding plakophilin-2 appears to be especially vulnerable as defects in this gene alone seem to account for about two thirds of the cases. This category of ARVC/D-based diseases and "sudden death" events resulting from altered desmosomal proteins also includes complex hereditary syndromes such as combinations of dermatological disorders ("woolly hair", diverse patterns of striate and 


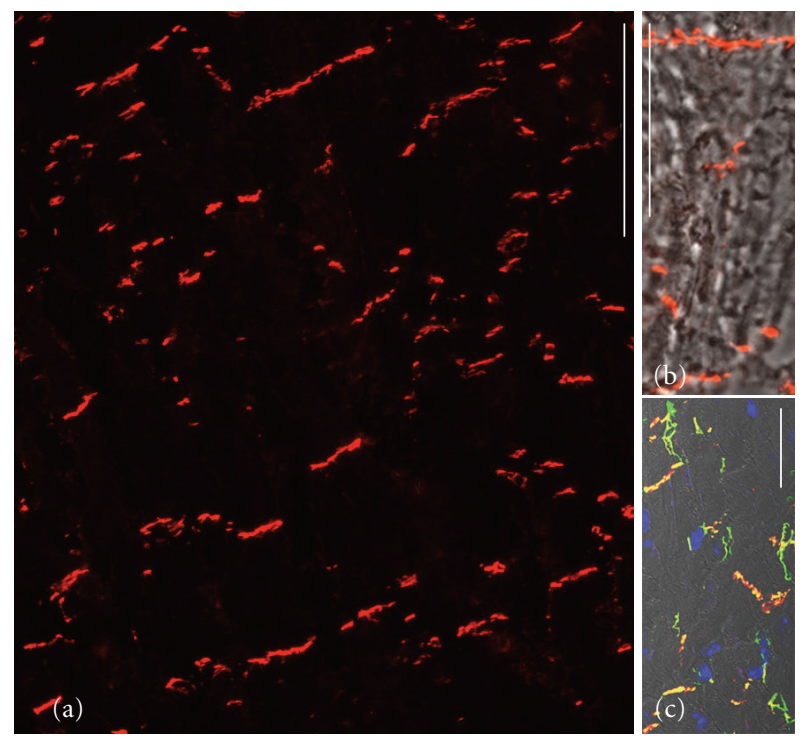

FIgURE 3: Micrographs showing the immunolocalization of the desmosomal plaque protein, desmoplakin, on cryostat sections through the murine myocardium. (a) Immunofluorescence micrograph showing the localization of desmoplakin (red) in all composite junction structures of the intercalated disks (IDs). (b) Immunofluorescence micrograph showing desmoplakin (red) labeling of the composite junctions on the background of phasecontrast optics. (c) Merged image showing plakophilin-2 (red), $\beta$ catenin (green) and nuclear DAPI-staining (blue), on an interference contrast microscopy background. Composite junctions (CJs) are characterized by their yellow merge colour whereas the zonulae adhaerentes and other AJs of the capillary endothelial cell layers here show only $\beta$-catenin-positivity. Bar in (a): $100 \mu \mathrm{m}$; bar in (b): $50 \mu \mathrm{m}$; bar in (c): $25 \mu \mathrm{m}$.

diffuse keratoderma changes, particularly in palmoplantar skin) and cardiac disease features such as in the classic "Naxos disease" type or the "Carvajal syndrome" subtype, first identified in the year 2000 in three Ecuadorian families, which may also include damages in both ventricles (for an anthology see [42]). The specific dominant and recessive forms of the human diseases ascribed to mutations of genes encoding desmosomal proteins have been dealt with in several specific recent review articles [42, 97-102].

\section{Adhering Junctions in the Specialized Cells of the Cardiac Conduction System}

The specialized cells of the mammalian cardiac conduction system are connected by three different types of AJs [103]: desmosomes, which in certain cell regions occur in impressively high packing density, as well as AJs and CJs (Figures $5(\mathrm{~b})-5(\mathrm{~d})$ ). The conductive cells of the ovine and bovine Purkinje fiber systems have been studied in special detail with respect to their nature as modified cardiomyocytes and to the various forms of junctions of which a major proportion is located at lateral cell-cell contact sites [103105]. These findings have led to the hypothesis that the abundance of apparently "normal-looking" desmosomes in

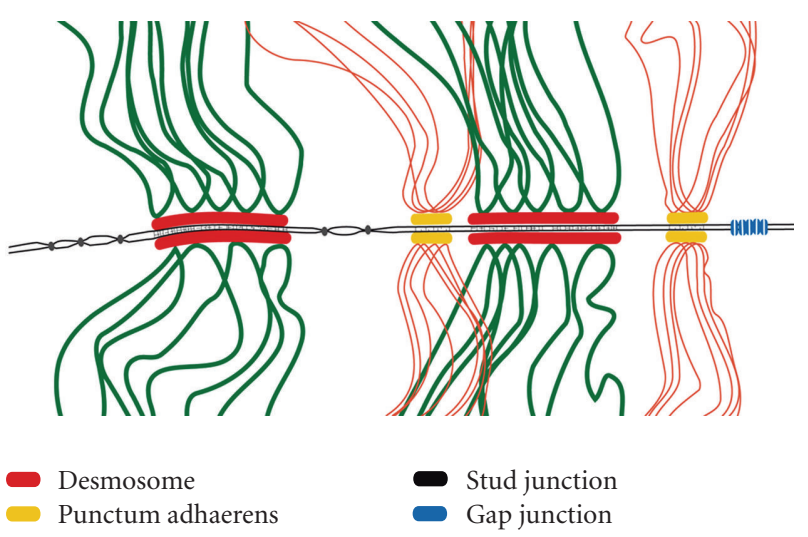

(a)

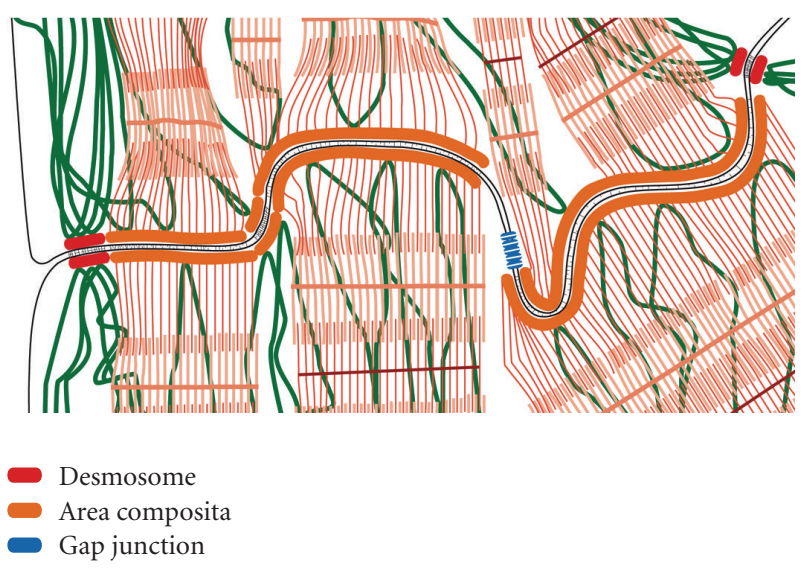

(b)

FIGURE 4: Schematic comparison of the different principles of organization of cell-cell junctions containing desmosomal proteins in mammalian epidermal and myocardiac tissue. (a) Junction organizations between epidermal keratinocytes as observed in the stratum spinosum. Note the densely spaced desmosomes (red plaques), which anchor bundles of intermediate sized filaments containing keratins (dark-green). Smaller adherens junctions (puncta adhaerentia, yellow plaques) anchor actin-microfilament bundles (red filaments). Furthermore, special types of tight junction-like structures, the small "stud junctions" (black dots), and channellike connexin paracrystals (gap junctions, blue) are also generally found. For details see $[29,30]$. (b) The area composita (composite junction, orange) structures of intercalated disks (ID) connecting cardiomyocytes of an adult mammalian heart. This amalgamated type of adhering junction is characterized by a mixture of typical desmosomal and AJ molecules. This kind of composite junction is the predominating adhering junction structure in the ID of the adult mammalian heart.

the conductive tissue might also-and perhaps primarilybe affected by the desmosomal protein mutations in cases of human ARVC/D (Table 2), as also suggested from the much higher conduction speed of these "cell fibers" (see, e.g., $[103,106,107])$.

The various size classes of the desmosomal proteinrich junctions connecting conduction cells are presented by desmoplakin immunoelectron microscopy in Figures 5(b)5 (d), including some very small junctions (arrowheads in 
TABle 2: During the last few years an avalanche of publications has appeared-and is still continuing to do so-showing the involvement of mutations in desmosomal components in the development of arrhythmogenic cardiomyopathies, including "sudden death" cases (for references see [10-12, 38, 40, 42-96]). Recent references reporting that certain mutations in human genes encoding desmosomal proteins and glycoproteins contribute to arrhythmogenic ventricular cardiomyopathies (ARVC).

\begin{tabular}{|c|c|c|}
\hline Protein & Reference & \\
\hline Plakophilin-2 & $\begin{array}{l}\text { Gerull et al. [43] } \\
\text { Antoniades et al. [44] } \\
\text { Calkins [45] } \\
\text { Nagaoka et al. [46] } \\
\text { Kannankeril et al. [47] } \\
\text { Dalal et al. [48] } \\
\text { Syrris et al. [49] } \\
\text { Tsatsopoulou et al. [50] } \\
\text { Van Tintelen et al. [51] } \\
\text { Awad et al. [60] } \\
\text { Lahtinen et al. [52] } \\
\text { Otterspoor et al. [53] }\end{array}$ & $\begin{array}{l}\text { Fidler et al. [38] } \\
\text { Joshi-Mukherje et al. [54] } \\
\text { Ram and Van Wagoner, [55] } \\
\text { Tandri et al. [56] } \\
\text { Wu et al. [57] } \\
\text { Qiu et al. [58] (5 cases) } \\
\text { Hall et al. [40] } \\
\text { Bhuiyan et al. [59] (23 cases) } \\
\text { den Haan et al. [64] (21 cases) } \\
\text { Xu et al. [61] (38 cases) } \\
\text { Bauce et al. [62] ( } 7 \text { cases) } \\
\text { Cox et al. [95] (58 cases) }\end{array}$ \\
\hline Desmoplakin & $\begin{array}{l}\text { Norgett et al. [84] } \\
\text { Rampazzo and Danieli [97] } \\
\text { Alcalai et al. [86] } \\
\text { Bauce et al. [77] } \\
\text { Norman et al. [85] } \\
\text { Sen-Chowdhry et al. [87] } \\
\text { Norgett et al. [75] } \\
\text { Uzumcu et al. [74] } \\
\text { Sen-Chowdhry et al. [88] }\end{array}$ & $\begin{array}{l}\text { Tsatsopoulou et al. [50] } \\
\text { Yang et al. [89] } \\
\text { den Haan et al. [64] (1 case) } \\
\text { Mahoney et al. [81] } \\
\text { Xu et al. [61] (10 cases) } \\
\text { Bauce et al. [62] ( } 5 \text { cases) } \\
\text { Cox et al. [95] ( } 1 \text { case) } \\
\text { Bolling et al. [96] }\end{array}$ \\
\hline Desmoglein-2 & $\begin{array}{l}\text { Pilichou et al. [90] } \\
\text { Tsatsopoulou et al. [50] } \\
\text { Awad et al. [60] } \\
\text { Syrris et al. [73] } \\
\text { Yu et al. [91] }\end{array}$ & $\begin{array}{l}\text { Bhuiyan et al. [59] ( } 4 \text { cases) } \\
\text { den Haan et al. [64] ( } 8 \text { cases) } \\
\text { Xu et al. [61] (10 cases) } \\
\text { Bauce et al. [62] ( } 4 \text { cases) } \\
\text { Cox et al. [95] (3 cases) }\end{array}$ \\
\hline Desmocollin-2 & $\begin{array}{l}\text { Heuser et al. [83] } \\
\text { Syrris et al. [72] } \\
\text { Beffagna et al. [79] } \\
\text { Bhuiyan et al. [59] (2 cases) }\end{array}$ & $\begin{array}{l}\text { Simpson et al. [76] } \\
\text { Xu et al. [61] ( } 4 \text { cases) } \\
\text { Bauce et al. [62] ( } 2 \text { cases) } \\
\text { Cox et al. }[95] \text { ( } 3 \text { cases) }\end{array}$ \\
\hline Plakoglobin & $\begin{array}{l}\text { McKoy et al. [80] } \\
\text { Protonotarios et al. [78, 82] } \\
\text { Kaplan et al. [71] } \\
\text { Garcia-Gras et al. [92] }\end{array}$ & $\begin{array}{l}\text { Asimaki et al. [93] } \\
\text { Asimaki et al. [94] } \\
\text { den Haan et al. [64] ( } 1 \text { case) } \\
\text { Xu et al. [61] (2 cases) }\end{array}$ \\
\hline
\end{tabular}

Selected review articles: Bazzi and Christiano [65]; Marcus et al. (Eds.) [42]; Awad et al. [66]; Corrado et al. [67]; Herren et al. [68]; Saffitz [69]; Sen-Chowdhry et al. [63].

First animal model (boxer dog): Oxford et al. [70].

Figure 5(b)). Frequently, a number of individual desmincontaining intermediate filaments can be resolved at such junctions (e.g., Figure 5(c)), often revealing closely-parallel plaque associations (e.g., arrows in Figure 5(d)).

\section{Desmosomal Plaque Proteins in Special Non-Desmosomal Adhering Junctions (Coniunctiones and Complexus Adhaerentes)}

Proteins of the plakophilin-subfamily of armadillo proteins are constitutive, apparently necessary components of desmosomal plaques $[13,108-113]$. Their special organizational role and architectonic importance has been demonstrated perhaps most convincingly in the case of plakophilin-2 by gene abrogation as well as siRNA-mediated mRNA reduction experiments [36, 37, 39-41]. Moreover, the functional importance of some plakophilins, in particular plakophilin2 , may extend beyond desmosomal plaques to gap junctions $[37,38]$ and into the interior of the cell, including certain cytoplasmic as well as nuclear complexes [114-116].

Recently, however, we have discovered that the occurrence of both plakophilin-2 and plakophilin-3 is not necessarily restricted to the plaques of desmosomes but that these proteins can also occur as constitutive molecules in plaques of some non-desmosomal junctions such as the puncta adhaerentia-like AJs of certain cell cultures [22, 23, 117] or in proliferatively active cells of certain tumors, for example in cardiac myxomata [118]. Here the rapid acquisition 


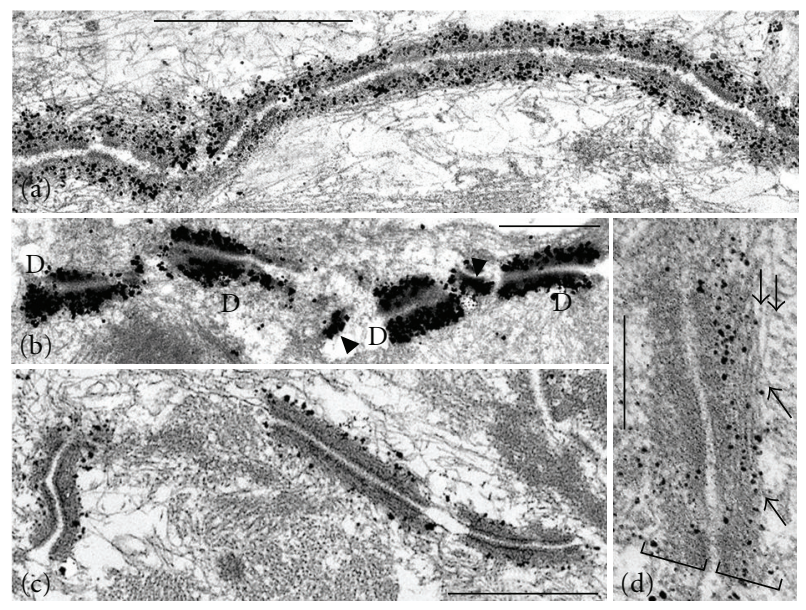

Figure 5: Immunoelectron microscopy of ultrathin sections through bovine myocardium (a) and Purkinje fibers ((b)-(d)) using antibodies against desmoplakin. (a) Immunogold labeling of a typical extended area composita structure in an intercalated disk (ID) of adult cardiomyocytes. (b) By contrast, note the relatively small desmoplakin-positive junctions that connect cells of the Purkinje fiber conductive system ((d), desmosomes; arrowheads denote some particularly small desmosome-like junction structures with asymmetric labeling). The desmoplakin-rich plaques of such junctions are very intensely labeled. (c) The morphology and the relatively close packing of the major type of junctions are similar to those of the area composita structures of adult mammalian cardiomyocytes. (d) High-magnification immunoelectron micrograph of a composite junction. Note the very close near parallel association of intermediate-sized filaments (some are denoted by arrows) with junctional plaques. Bars in (a) and (b): $1 \mu \mathrm{m}$; bar in (c): $0.25 \mu \mathrm{m}$.

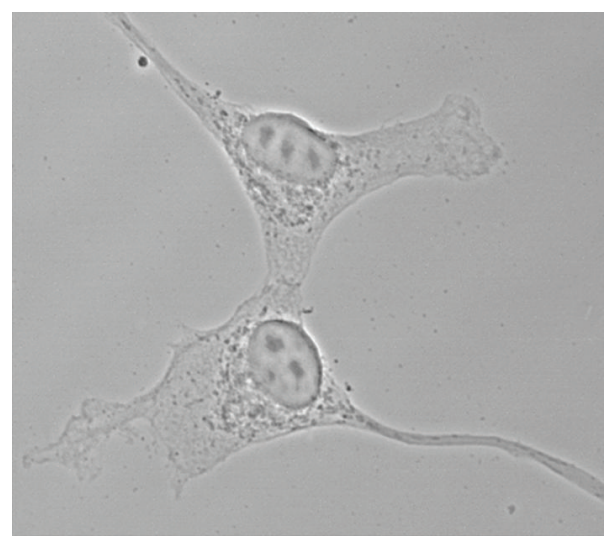

(a)

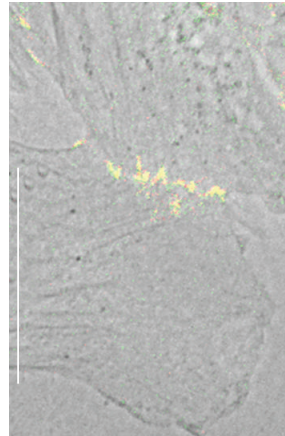

(b)

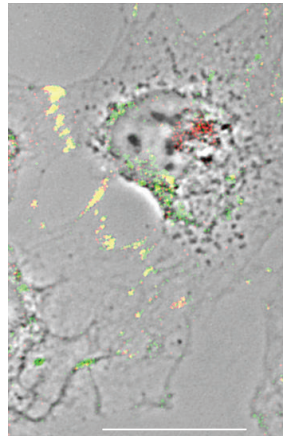

(c)

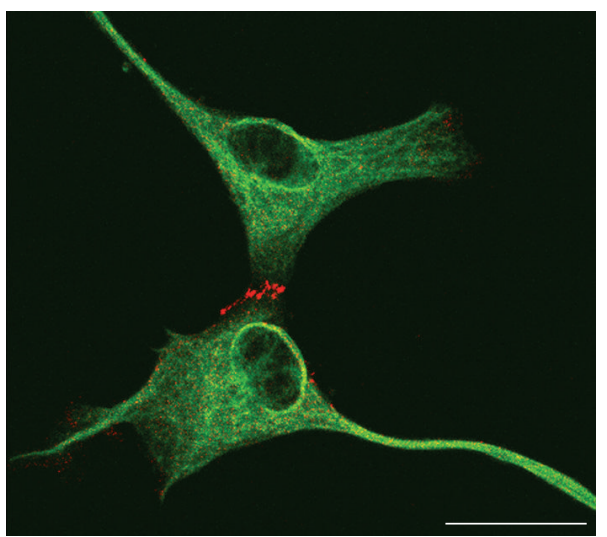

(a')

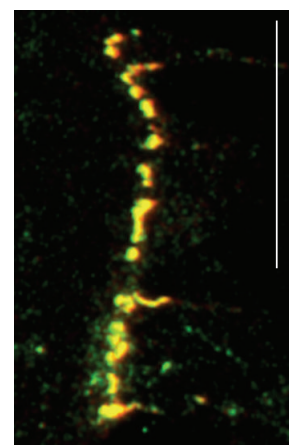

(e)

FIgURE 6: Double-label immunofluorescence micrographs, showing the localization of the "desmosomal protein", plakophilin-2, in mesenchymally derived cultures of valvular interstitial cells (VICs). (a), (a') Phase contrast and immunofluorescence micrograph showing ovine VICs forming clusters of AJs positive for the typical desmosomal plaque component plakophilin-2 (red; vimentin filaments are labeled in green). (b)-(d) Represent merged images of ovine VICs, showing colocalization staining (yellow) of plakophilin-2 (red) with typical AJ proteins such as cadherin-11 (green, (b)), $\beta$-catenin (green, (c)), protein p120 (green, (d)) all on a phase contrast background. (e) Human VICs exhibit similar colocalization of plakophilin-2 (red) here with $\mathrm{N}$-cadherin (green) as shown by the yellow merge colour (for further details see [23]). Bar in (a): $25 \mu \mathrm{m}$; bar in (b): $30 \mu \mathrm{m}$; bars in (c) and (d): $20 \mu \mathrm{m}$; bar in E: $10 \mu \mathrm{m}$. 
of plakophilin-2 to the non-desmosomal plaques of these tumor cell AJs, in particular the fact that it appears in the earliest in vitro culture passages of cardiac valvular interstitial cells from various mammalian species [23], suggests that the addition of plakophilin-2 alone-or together with plakophilin-3-to these junctions is somehow related to the induction of proliferation and cell cycle growth. It is therefore likely that in the future the systematic examination of the presence of plakophilins in such AJs will give valuable diagnostic informations. Figures 6(a)-6(e) present the early integration of plakophilin-2 into a series of small puncta adhaerentia connecting interstitial cells freshly brought from cardiac valve matrix tissue into cell culture (for details see [23]).

The junctional system connecting the endothelial cells of blood and lymph vessels is obviously of great biological importance and has been studied extensively (reviews: [119, 120]). There is, however, a special category of variously-sized and -shaped AJs which connect certain types of endothelial cells in some parts of the lymphatic system, including the three-dimensionally branched "virgultar" cells of lymph node sinus as well as specific cutaneous and other peripheral lymph capillaries, which are characterized by AJs containing in addition desmoplakin as a major plaque protein, in most cases probably in combination with plakoglobin $[18,121-$ 123]. The existence of such complexus adhaerentes in special parts of the vascular endothelial system has since been confirmed several times ([124-126], for a recent review see [19]). The formation of plaque complexes of VEcadherin with desmoplakin and plakoglobin has also been demonstrated for dermal capillary endothelium in special molecular assembly experiments [127].

Beyond this role of desmoplakin as a regular constituent of the plaques of such "complex junctions" in certain lymphatic endothelia of the mature body a fundamental and general role of desmoplakin in the formation of the vascular endothelial system is also indicated by the transgene embryogenesis studies of Gallicano et al. [128, 129]. Thus, the complexus adhaerens junctions have to be added to the list of novel kinds of adhering junctions in their own right (see Table 1; for recent reviews see: $[19,130,131]$ ).

\section{Dispersed, Non-Junction Bound States of Desmosomal Cadherins: Desmoglein Dsg2}

Desmosomal cadherins typically associate with each other and form close-packed cis-clusters in the membranes of cytoplasmic vesicles, then exocytose to form a "half-junction" on the cell surface and under sufficient $\mathrm{Ca}^{2+}$-concentration may further associate head-to-head in transform with another "half-junction", usually a domain of an adjacent cell, to a symmetrical junction [132-137]. Isolated, that is, non-junction-bound, desmosomal cadherin molecules that have not been included in desmosome structures and consequently may be dispersed over extended parts of the plasma membrane until recently had not been observed in natural cells. Only in certain cell culture lines deficient of most junction components such as the human fibrosarcoma HT-1080 cells states of the isolated desmosomal cadherin, Dsg2, have been described to occur on cell surfaces and could be integrated into junction-like structures only upon introduction of further desmosomal proteins $[137,138]$.

Thus it was with great surprise when we noted the occurrence of Dsg2 molecules dispersed over large portions of the surface membrane of certain cultures of human melanocytes or neval cells as well as on surfaces of a subtype of melanoma cells in situ and in culture [139, 140]. As far as it could be concluded from the biochemical analyses and immunolocalization experiments so far performed, these Dsg2 glycoprotein molecules were not stably complexed with specific other transmembrane or with any plaque molecules but nevertheless seemed to be somehow involved in close membrane-to-membrane associations. It is obvious that such stages, that is, dispersed, non-junctionbound desmosomal cadherins will have to be studied with special care as they point to the existence of yet unknown, radically different cell-cell adhesion mechanisms involving desmosomal cadherins.

\section{Acknowledgments}

The authors thank Caecilia Kuhn and Christine Grund for their excellent technical assistance, the "Deutsche Krebshilfe" (Grant 10-2049-Fr1 to W. W. Franke), and the German Ministry for Research and Technology (Program Regenerative Medicine, START-MSC, to W. W. Franke) for financial support. Sebastian Pieperhoff thanks in particular the Canadian Government (DFAIT) for funding of a Postodoctoral Research Fellowship (PDRF) during the tenure 03/200803/2009 and the German Science Foundation (DFG) for funding of a Postodctoral Research Fellowship during the following tenure.

\section{References}

[1] M. G. Farquhar and G. E. Palade, "Junctional complexes in various epithelia," The Journal of Cell Biology, vol. 17, pp. 375-412, 1963.

[2] P. Drochmans, C. Freudenstein, J. C. Wanson, et al., "Structure and biochemical composition of desmosomes and tonofilaments isolated from calf muzzle epidermis," Journal of Cell Biology, vol. 79, pp. 427-443, 1978.

[3] P. Cowin, W. W. Franke, C. Grund, H. P. Kapprell, and J. Kartenbeck, "The desmosome-intermediate filament complex," in The Cell in Contact, G. M. Edelman and J. P. Thiery, Eds., pp. 427-460, John Wiley \& Sons, New York, NY, USA, 1985.

[4] L. M. Godsel, S. Getsios, A. C. Huen, and K. J. Green, "The molecular composition and function of desmosomes," in Cell Adhesion, J. Behrens and W. J. Nelson, Eds., pp. 137-193, Springer, Heidelberg, Germany, 2004.

[5] D. Garrod and M. Chidgey, "Desmosome structure, composition and function," Biochimica et Biophysica Acta, vol. 1778, no. 3, pp. 572-587, 2008.

[6] A. Schmidt and P. J. Koch, "Desmosomes in development and disease," in Cell Junctions, S. E. LaFlamme and A. P. Kowalczyk, Eds., pp. 235-249, Wiley-VCH, Weinheim, Germany, 2008. 
[7] W. W. Franke, "Discovering the molecular components of intercellular junctions-a historical view," in Cell-Cell Junctions, W. J. Nelson and E. Fuchs, Eds., Cold Spring Harbor Perspectives in Biology, pp. 1-34, Cold Spring Harbor Laboratory Press, Cold Spring Harbor, NY, USA, 2010.

[8] S. Pieperhoff and W. W. Franke, "The area composita of adhering junctions connecting heart muscle cells of vertebrates. VI. Different precursor structures in non-mammalian species," European Journal of Cell Biology, vol. 87, no. 7, pp. 413-430, 2008.

[9] J. Waschke, “The desmosome and pemphigus," Histochemistry and Cell Biology, vol. 130, no. 1, pp. 21-54, 2008.

[10] W. W. Franke, E. Schmid, C. Grund, et al., "Antibodies to high molecular weight polypeptides of desmosomes: specific localization of a class of junctional proteins in cells and tissues," Differentiation, vol. 20, no. 3, pp. 217-241, 1981.

[11] W. W. Franke, R. Moll, D. L. Schiller, E. Schmid, J. Kartenbeck, and H. Mueller, "Desmoplakins of epithelial and myocardial desmosomes are immunologically and biochemically related," Differentiation, vol. 23, no. 2, pp. 115-127, 1982.

[12] P. Cowin, H.-P. Kapprell, and W. W. Franke, "Plakoglobin: a protein common to different kinds of intercellular adhering junctions," Cell, vol. 46, no. 7, pp. 1063-1073, 1986.

[13] C. Mertens, C. Kuhn, and W. W. Franke, "Plakophilins 2a and 2b: constitutive proteins of dual location in the karyoplasm and the desmosomal plaque," Journal of Cell Biology, vol. 135, no. 4, pp. 1009-1025, 1996.

[14] W. W. Franke, C. M. Borrmann, C. Grund, and S. Pieperhoff, "The area composita of adhering junctions connecting heart muscle cells of vertebrates. I. Molecular definition in intercalated disks of cardiomyocytes by immunoelectron microscopy of desmosomal proteins," European Journal of Cell Biology, vol. 85, no. 2, pp. 69-82, 2006.

[15] S. Pieperhoff and W. W. Franke, "The area composita of adhering junctions connecting heart muscle cells of vertebrates-IV: coalescence and amalgamation of desmosomal and adhaerens junction components-late processes in mammalian heart development," European Journal of Cell Biology, vol. 86, no. 7, pp. 377-391, 2007.

[16] S. Goossens, B. Janssens, S. Bonne, et al., "A unique and specific interaction between alphaT-catenin and plakophilin2 in the area composita, the mixed-type junctional structure of cardiac intercalated discs," Journal of Cell Science, vol. 120, no. 12, part 2, pp. 2126-2136, 2007.

[17] T. S. Seeger, D. Frank, C. Rohr, et al., "Myozap, a novel intercalated disc protein, activates serum response factordependent signaling and is required to maintain cardiac function in vivo," Circulation Research, vol. 106, no. 5, pp. 880-890, 2010.

[18] B. Hämmerling, C. Grund, J. Boda-Heggemann, R. Moll, and W. W. Franke, "The complexus adhaerens of mammalian lymphatic endothelia revisited: a junction even more complex than hitherto thought," Cell and Tissue Research, vol. 324, no. 1, pp. 55-67, 2006.

[19] R. Moll, E. Sievers, B. Hämmerling, et al., "Endothelial and virgultar cell formations in the mammalian lymph node sinus: endothelial differentiation morphotypes characterized by a special kind of junction (complexus adhaerens)," Cell and Tissue Research, vol. 335, no. 1, pp. 109-141, 2009.
[20] R. Paffenholz, C. Kuhn, C. Grund, S. Stehr, and W. W. Franke, "The arm-repeat protein NPRAP (neurojungin) is a constituent of the plaques of the outer limiting zone in the retina, defining a novel type of adhering junction," Experimental Cell Research, vol. 250, no. 2, pp. 452-464, 1999.

[21] J. Boda-Heggemann, A. Regnier-Vigouroux, and W. W. Franke, "Beyond vessels: occurrence and regional clustering of vascular endothelial (VE-) cadherin-containing junctions in non-endothelial cells," Cell and Tissue Research, vol. 335, no. 1, pp. 49-65, 2009.

[22] S. Rickelt, S. Winter-Simanowski, E. Noffz, C. Kuhn, and W. W. Franke, "Upregulation of plakophilin-2 and its acquisition to adherens junctions identifies a novel molecular ensemble of cell-cell-attachment characteristic for transformed mesenchymal cells," International Journal of Cancer, vol. 125, no. 9, pp. 2036-2048, 2009.

[23] M. Barth, H. Schumacher, C. Kuhn, P. Akhyari, A. Lichtenberg, and W. W. Franke, "Cordial connections: molecular ensembles and structures of adhering junctions connecting interstitial cells of cardiac valves in situ and in cell culture," Cell and Tissue Research, vol. 337, no. 1, pp. 63-77, 2009.

[24] M. Amagai, "Desmoglein as a target in autoimmunity and infection," Journal of the American Academy of Dermatology, vol. 48, no. 2, pp. 244-252, 2003.

[25] J. C. R. Jones, K. M. Yokoo, and R. D. Goldman, "Further analysis of pemphigus autoantibodies and their use in studies on the heterogeneity, structure, and function of desmosomes," Journal of Cell Biology, vol. 102, no. 3, pp. 1109-1117, 1986.

[26] A. S. Payne, Y. Hanakawa, M. Amagai, and J. R. Stanley, "Desmosomes and disease: pemphigus and bullous impetigo," Current Opinion in Cell Biology, vol. 16, no. 5, pp. 536-543, 2004.

[27] M. G. Mahoney, Z. H. Wang, and J. R. Stanley, "Pemphigus vulgaris and pemphigus foliaceus antibodies are pathogenic in plasminogen activator knockout mice," Journal of Investigative Dermatology, vol. 113, no. 1, pp. 22-25, 1999.

[28] M. G. Mahoney, Z. Wang, K. Rothenberger, P. J. Koch, M. Amagai, and J. R. Stanley, "Explanations for the clinical and microscopic localization of lesions in pemphigus foliaceus and vulgaris," Journal of Clinical Investigation, vol. 103, no. 4, pp. 461-468, 1999.

[29] L. Langbein, C. Grund, C. Kuhn, et al., "Tight junctions and compositionally related junctional structures in mammalian stratified epithelia and cell cultures derives therefrom," European Journal of Cell Biology, vol. 81, no. 8, pp. 419-435, 2002.

[30] H. Schlüter, I. Moll, H. Wolburg, and W. W. Franke, "The different structures containing tight junction proteins in epidermal and other stratified epithelial cells, including squamous cell metaplasia," European Journal of Cell Biology, vol. 86, no. 11-12, pp. 645-655, 2007.

[31] M. Leu, E. Ehler, and J.-C. Perriard, "Characterisation of postnatal growth of the murine heart," Anatomy and Embryology, vol. 204, no. 3, pp. 217-224, 2001.

[32] A. Hirschy, F. Schatzmann, E. Ehler, and J.-C. Perriard, "Establishment of cardiac cytoarchitecture in the developing mouse heart," Developmental Biology, vol. 289, no. 2, pp. 430441, 2006. 
[33] C. M. Borrmann, C. Grund, C Kuhn, I. Hofmann, S. Pieperhoff, and W. W. Franke, "The area composita of adhering junctions connecting heart muscle cells of vertebrates. II. Colocalizations of desmosomal and fascia adhaerens molecules in the intercalated disk," European Journal of Cell Biology, vol. 85, no. 6, pp. 469-485, 2006.

[34] S. Pieperhoff, W. Bennett, and A. P. Farrell, "The intercellular organization of the two muscular systems in the adult salmonid heart, the compact and the spongy myocardium," Journal of Anatomy, vol. 215, no. 5, pp. 536-547, 2009.

[35] P. Ruiz, V. Brinkmann, B. Ledermann, et al., "Targeted mutation of plakoglobin in mice reveals essential functions of desmosomes in the embryonic heart," Journal of Cell Biology, vol. 135, no. 1, pp. 215-225, 1996.

[36] K. S. Grossmann, C. Grund, J. Huelsken, et al., "Requirement of plakophilin 2 for heart morphogenesis and cardiac junction formation," Journal of Cell Biology, vol. 167, no. 1, pp. 149-160, 2004.

[37] E. M. Oxford, H. Musa, K. Maass, W. Coombs, S. M. Taffet, and M. Delmar, "Connexin43 remodeling caused by inhibition of plakophilin-2 expression in cardiac cells," Circulation Research, vol. 101, no. 7, pp. 703-711, 2007.

[38] L. M. Fidler, G. J. Wilson, F. Liu, et al., "Abnormal connexin43 in arrhythmogenic right ventricular cardiomyopathy caused by plakophilin-2 mutations," Journal of Cellular and Molecular Medicine, vol. 13, no. 10, pp. 4219-4228, 2008.

[39] S. Pieperhoff, H. Schumacher, and W. W. Franke, "The area composita of adhering junctions connecting heart muscle cells of vertebrates. V. The importance of plakophilin-2 demonstrated by small interference RNA-mediated knockdown in cultured rat cardiomyocytes," European Journal of Cell Biology, vol. 87, no. 7, pp. 399-411, 2008.

[40] C. Hall, S. Li, H. Li, V. Creason, and J. K. Wahl III, "Arrhythmogenic right ventricular cardiomyopathy plakophilin-2 mutations disrupt desmosome assembly and stability," Cell Communication and Adhesion, vol. 16, no. 1-3, pp. 15-27, 2009.

[41] P. Y. Sato, H. Musa, W. Coombs, et al., "Loss of plakophilin2 expression leads to decreased sodium current and slower conduction velocity in cultured cardiac myocytes," Circulation Research, vol. 105, no. 6, pp. 523-526, 2009.

[42] F. I. Marcus, A. Nava, and G. Thiene, Arrhythmogenic RV Cardiomyopathy/Dysplasia, Springer, Heidelberg, Germany, 2007.

[43] B. Gerull, A. Heuser, T. Wichter, et al., "Mutations in the desmosomal protein plakophilin-2 are common in arrhythmogenic right ventricular cardiomyopathy," Nature Genetics, vol. 36, no. 11, pp. 1162-1164, 2004.

[44] L. Antoniades, A. Tsatsopoulou, A. Anastasakis, et al., "Arrhythmogenic right ventricular cardiomyopathy caused by deletions in plakophilin-2 and plakoglobin (Naxos disease) in families from Greece and Cyprus: genotypephenotype relations, diagnostic features and prognosis," European Heart Journal, vol. 27, no. 18, pp. 2208-2216, 2006.

[45] H. Calkins, "Arrhythmogenic right-ventricular dysplasia/cardiomyopathy," Current Opinion in Cardiology, vol. 21 , no. 1 , pp. 55-63, 2006.

[46] I. Nagaoka, K. Matsui, T. Ueyama, et al., "Novel mutation of plakophilin-2 associated with arrhythmogenic right ventricular cardiomyopathy," Circulation Journal, vol. 70, no. 7, pp. 933-935, 2006.

[47] P. J. Kannankeril, Z. A. Bhuiyan, D. Darbar, M. M. A. M. Mannens, A. A. M. Wilde, and D. M. Roden, "Arrhythmogenic right ventricular cardiomyopathy due to a novel plakophilin 2 mutation: wide spectrum of disease in mutation carriers within a family," Heart Rhythm, vol. 3, no. 8, pp. 939-944, 2006.

[48] D. Dalal, L. H. Molin, J. Piccini, et al., "Clinical features of arrhythmogenic right ventricular dysplasia/ cardiomyopathy associated with mutations in plakophilin-2," Circulation, vol. 113, no. 13, pp. 1641-1649, 2006.

[49] P. Syrris, D. Ward, A. Asimaki, et al., "Clinical expression of plakophilin-2 mutations in familial arrhythmogenic right ventricular cardiomyopathy," Circulation, vol. 113, no. 3, pp. 356-364, 2006.

[50] A. A. Tsatsopoulou, N. I. Protonotarios, and W. J. McKenna, "Arrhythmogenic right ventricular dysplasia, a cell adhesion cardiomyopathy: insights into disease pathogenesis from preliminary genotype-phenotype assessment," Heart, vol. 92, no. 12, pp. 1720-1723, 2006.

[51] J. P. Van Tintelen, M. M. Entius, Z. A. Bhuiyan, et al., "Plakophilin-2 mutations are the major determinant of familial arrhythmogenic right ventricular dysplasia/cardiomyopathy," Circulation, vol. 113, no. 13, pp. 1650-1658, 2006.

[52] A. M. Lahtinen, A. Lehtonen, M. Kaartinen, et al., "Plakophilin-2 missense mutations in arrhythmogenic right ventricular cardiomyopathy," International Journal of Cardiology, vol. 126, no. 1, pp. 92-100, 2008.

[53] L. C. Otterspoor, C. L. A. Reichert, M. J. M. Cramer, Z. A. Bhuiyan, A. A. M. Wilde, and R. N. W. Hauer, "Arrhythmogenic right ventricular cardiomyopathy: asymptomatic to life threatening as illustrated by the cases of two sisters," Netherlands Heart Journal, vol. 15, no. 10, pp. 348-353, 2007.

[54] R. Joshi-Mukherjee, W. Coombs, H. Musa, E. Oxford, S. Taffet, and M. Delmar, "Characterization of the molecular phenotype of two arrhythmogenic right ventricular cardiomyopathy (ARVC)-related plakophilin-2 (PKP2) mutations," Heart Rhythm, vol. 5, no. 12, pp. 1715-1723, 2008.

[55] R. Ram and D. R. Van Wagoner, "Plakophilin-2 mutations as a cause of arrhythmogenic right ventricular cardiomyopathy: progress toward linking structural with functional changes," Heart Rhythm, vol. 5, no. 12, pp. 1724-1725, 2008.

[56] H. Tandri, A. Asimaki, D. Dalal, J. E. Saffitz, M. K. Halushka, and H. Calkins, "Gap junction remodeling in a case of arrhythmogenic right ventricular dysplasia due to plakophilin-2 mutation," Journal of Cardiovascular Electrophysiology, vol. 19, no. 11, pp. 1212-1214, 2008.

[57] S.-L. Wu, P.-N. Wang, Y.-S. Hou, et al., "Mutation of plakophilin-2 gene in arrhythmogenic right ventricular cardiomyopathy," Chinese Medical Journal, vol. 122, no. 4, pp. 403-407, 2009.

[58] X. Qiu, W. Liu, D. Hu, et al., "Mutations of plakophilin2 in Chinese with arrhythmogenic right ventricular dysplasia/cardiomyopathy," American Journal of Cardiology, vol. 103, no. 10, pp. 1439-1444, 2009.

[59] Z. A. Bhuiyan, J. D. Jongbloed, J. van der Smagt, et al., "Desmoglein-2 and desmocollin-2 mutations in dutch arrhythmogenic right ventricular dysplasia/cardiomypathy patients: results from a multicenter study," Circulation: Cardiovascular Genetics, vol. 2, no. 5, pp. 418-427, 2009.

[60] M. M. Awad, D. Dalal, C. Tichnell, et al., "Recessive arrhythmogenic right ventricular dysplasia due to novel cryptic splice mutation in PKP2," Human Mutation, vol. 27, no. 11, p. 1157, 2006.

[61] T. Xu, Z. Yang, M. Vatta, et al., "Compound and digenic heterozygosity contributes to arrhythmogenic right ventricular cardiomyopathy," Journal of the American College of Cardiology, vol. 55, no. 6, pp. 587-597, 2010. 
[62] B. Bauce, A. Nava, G. Beffagna, et al., "Multiple mutations in desmosomal proteins encoding genes in arrhythmogenic right ventricular cardiomyopathy/dysplasia," Heart Rhythm, vol. 7, no. 1, pp. 22-29, 2010.

[63] S. Sen-Chowdhry, R. D. Morgan, J. C. Chambers, and W. J. McKenna," "Arrhythmogenic cardiomyopathy: etiology, diagnosis, and treatment," Annual Review of Medicine, vol. 61, pp. 233-253, 2010.

[64] A. D. den Haan, B. Y. Tan, M. N. Zikusoka, et al., "Comprehensive desmosome mutation analysis in north americans with arrhythmogenic right ventricular dysplasia/cardiomyopathy," Circulation. Cardiovascular Genetics, vol. 2, no. 5, pp. 428-435, 2009.

[65] H. Bazzi and A. M. Christiano, "Broken hearts, woolly hair, and tattered skin: when desmosomal adhesion goes awry," Current Opinion in Cell Biology, vol. 19, no. 5, pp. 515-520, 2007.

[66] M. M. Awad, H. Calkins, and D. P. Judge, "Mechanisms of disease: molecular genetics of arrhythmogenic right ventricular dysplasia/cardiomyopathy," Nature Clinical Practice Cardiovascular Medicine, vol. 5, no. 5, pp. 258-267, 2008.

[67] D. Corrado, C. Basso, and G. Thiene, "Arrhythmogenic right ventricular cardiomyopathy: an update," Heart, vol. 95, no. 9, pp. 766-773, 2009.

[68] T. Herren, P. A. Gerber, and F. Duru, "Arrhythmogenic right ventricular cardiomyopathy/dysplasia: a not so rare "disease of the desmosome" with multiple clinical presentations," Clinical Research in Cardiology, vol. 98, no. 3, pp. 141-158, 2009.

[69] J. E. Saffitz, "Arrhythmogenic cardiomyopathy and abnormalities of cell-to-cell coupling," Heart Rhythm, vol. 6, no. 8, pp. S62-S65, 2009.

[70] E. M. Oxford, M. Everitt, W. Coombs, et al., "Molecular composition of the intercalated disc in a spontaneous canine animal model of arrhythmogenic right ventricular dysplasia/cardiomyopathy," Heart Rhythm, vol. 4, no. 9, pp. 1196-1205, 2007.

[71] S. R. Kaplan, J. J. Gard, N. Protonotarios, et al., "Remodeling of myocyte gap junctions in arrhythmogenic right ventricular cardiomyopathy due to a deletion in plakoglobin (Naxos disease)," Heart Rhythm, vol. 1, no. 1, pp. 3-11, 2004.

[72] P. Syrris, D. Ward, A. Evans, et al., "Arrhythmogenic right ventricular dysplasia/cardiomyopathy associated with mutations in the desmosomal gene desmocollin-2," American Journal of Human Genetics, vol. 79, no. 5, pp. 978-984, 2006.

[73] P. Syrris, D. Ward, A. Asimaki, et al., "Desmoglein-2 mutations in arrhythmogenic right ventricular cardiomyopathy: a genotype-phenotype characterization of familial disease," European Heart Journal, vol. 28, no. 5, pp. 581-588, 2007.

[74] A. Uzumcu, E. E. Norgett, A. Dindar, et al., "Loss of desmoplakin isoform I causes early onset cardiomyopathy and heart failure in a Naxos-like syndrome," Journal of Medical Genetics, vol. 43, no. 2, p. e5, 2006.

[75] E. E. Norgett, T. W. Lucke, B. Bowers, C. S. Munro, I. M. Leigh, and D. P. Kelsell, "Early death from cardiomyopathy in a family with autosomal dominant striate palmoplantar keratoderma and woolly hair associated with a novel insertion mutation in desmoplakin," Journal of Investigative Dermatology, vol. 126, no. 7, pp. 1651-1654, 2006.

[76] M. A. Simpson, S. Mansour, D. Ahnood, et al., "Homozygous mutation of desmocollin-2 in arrhythmogenic right ventricular cardiomyopathy with mild palmoplantar keratoderma and woolly hair," Cardiology, vol. 113, no. 1, pp. 28-34, 2009.
[77] B. Bauce, C. Basso, A. Rampazzo, et al., "Clinical profile of four families with arrhythmogenic right ventricular cardiomyopathy caused by dominant desmoplakin mutations," European Heart Journal, vol. 26, no. 16, pp. 1666-1675, 2005.

[78] N. Protonotarios, A. Tsatsopoulou, A. Anastasakis, et al., "Genotype-phenotype assessment in autosomal recessive arrhythmogenic right ventricular cardiomyopathy (Naxos disease) caused by a deletion in plakoglobin," Journal of the American College of Cardiology, vol. 38, no. 5, pp. 1477-1484, 2001.

[79] G. Beffagna, M. De Bortoli, A. Nava, et al., "Missense mutations in Desmocollin-2 N-terminus, associated with arrhythmogenic right ventricular cardiomyopathy, affect intracellular localization of desmocollin-2 in vitro," $B M C$ Medical Genetics, vol. 8, article 65, 2007.

[80] G. McKoy, N. Protonotarios, A. Crosby, et al., "Identification of a deletion in plakoglobin in arrhythmogenic right ventricular cardiomyopathy with palmoplantar keratoderma and woolly hair (Naxos disease)," Lancet, vol. 355, no. 9221, pp. 2119-2124, 2000.

[81] M. G. Mahoney, S. Sadowski, D. Brennan, et al., "Compound heterozygous desmoplakin mutations result in a phenotype with a combination of myocardial, skin, hair, and enamel abnormalities," Journal of Investigative Dermatology, vol. 130, no. 4, pp. 968-978, 2010.

[82] N. I. Protonotarios, A. A. Tsatsopoulou, and K. A. Gatzoulis, "Arrhythmogenic right ventricular cardiomyopathy caused by a deletion in plakoglobin (Naxos disease)," Cardiac Electrophysiology Review, vol. 6, no. 1-2, pp. 72-80, 2002.

[83] A. Heuser, E. R. Plovie, P. T. Ellinor, et al., "Mutant desmocollin-2 causes arrhythmogenic right ventricular cardiomyopathy," American Journal of Human Genetics, vol. 79, no. 6, pp. 1081-1088, 2006.

[84] E. E. Norgett, S. J. Hatsell, L. Carvajal-Huerta, et al., "Recessive mutation in desmoplakin disrupts desmoplakinintermediate filament interactions and causes dilated cardiomyopathy, woolly hair and keratoderma," Human Molecular Genetics, vol. 9, no. 18, pp. 2761-2766, 2000.

[85] M. Norman, M. Simpson, J. Mogensen, et al., "Novel mutation in desmoplakin causes arrhythmogenic left ventricular cardiomyopathy," Circulation, vol. 112, no. 5, pp. 636-642, 2005.

[86] R. Alcalai, S. Metzger, S. Rosenheck, V. Meiner, and T. Chajek-Shaul, "A recessive mutation in desmoplakin causes arrhythmogenic right ventricular dysplasia, skin disorder, and woolly hair," Journal of the American College of Cardiology, vol. 42, no. 2, pp. 319-327, 2003.

[87] S. Sen-Chowdhry, P. Syrris, and W. J. McKenna, "Genetics of right ventricular cardiomyopathy," Journal of Cardiovascular Electrophysiology, vol. 16, no. 8, pp. 927-935, 2005.

[88] S. Sen-Chowdhry, P. Syrris, D. Ward, A. Asimaki, E. Sevdalis, and W. J. McKenna, "Clinical and genetic characterization of families with arrhythmogenic right ventricular dysplasia/cardiomyopathy provides novel insights into patterns of disease expression," Circulation, vol. 115, no. 13, pp. 1710-1720, 2007.

[89] Z. Yang, N. E. Bowles, S. E. Scherer, et al., "Desmosomal dysfunction due to mutations in desmoplakin causes arrhythmogenic right ventricular dysplasia/cardiomyopathy," Circulation Research, vol. 99, no. 6, pp. 646-655, 2006.

[90] K. Pilichou, A. Nava, C. Basso, et al., "Mutations in desmoglein-2 gene are associated with arrhythmogenic right ventricular cardiomyopathy," Circulation, vol. 113, no. 9, pp. 1171-1179, 2006. 
[91] C.-C. Yu, C.-H. Yu, C.-H. Hsueh, et al., "Arrhythmogenic right ventricular dysplasia: clinical characteristics and identification of novel desmosome gene mutations," Journal of the Formosan Medical Association, vol. 107, no. 7, pp. 548-558, 2008.

[92] E. Garcia-Gras, R. Lombardi, M. J. Giocondo, et al., "Suppression of canonical Wnt/ $\beta$-catenin signaling by nuclear plakoglobin recapitulates phenotype of arrhythmogenic right ventricular cardiomyopathy," Journal of Clinical Investigation, vol. 116, no. 7, pp. 2012-2021, 2006.

[93] A. Asimaki, P. Syrris, T. Wichter, P. Matthias, J. E. Saffitz, and W. J. McKenna, "A novel dominant mutation in plakoglobin causes arrhythmogenic right ventricular cardiomyopathy," American Journal of Human Genetics, vol. 81, no. 5, pp. 964-973, 2007.

[94] A. Asimaki, H. Tandri, H. Huang, et al., "A new diagnostic test for arrhythmogenic right ventricular cardiomyopathy," The New England Journal of Medicine, vol. 360, no. 11, pp. 1075-1084, 2009.

[95] M. G. Cox, J. J. Vandersmagt, M. Noorman, et al., "ARVD/C diagnosis: impact of new task force criteria," Circulation: Arrhythmia and Electrophysiology, vol. 3, no. 2, pp. 126-133, 2010.

[96] M. C. Bolling, M. J. Veenstra, M. F. Jonkmann, et al., “Lethal acantholytic epidermolysis bullosa due to a novel homozygous deletion in DSP: expanding the phenotype and implications for desmoplakin functions in skin and heart," British Journal of Dermatology, vol. 162, no. 6, pp. 1388-1394, 2010.

[97] A. Rampazzo and G. A. Danieli, "Advances in genetics: dominant forms," in Arrhythmogenic $R V$ Cardiomyopathy/Dysplasia, F. I. Marcus, A. Nava, and G. Thiene, Eds., pp. 7-14, Springer, Heidelberg, Germany, 2007.

[98] N. Protonotarios and A. Tsatsopoulou, "Advances in genetics: dominant forms," in Arrhythmogenic RV Cardiomyopathy/Dysplasia, F. I. Marcus, A. Nava, and G. Thiene, Eds., pp. 15-20, Springer, Heidelberg, Germany, 2007.

[99] B. Bauce and A. Nava, "Genotype-phenotype correlations," in Arrhythmogenic RV Cardiomyopathy/Dysplasia, F. I. Marcus, A. Nava, and G. Thiene, Eds., pp. 21-28, Springer, Heidelberg, Germany, 2007.

[100] C. Basso and G. Thiene, "Autopsy and endomyocardial biopsy findings," in Arrhythmogenic RV Cardiomyopathy/Dysplasia, F. I. Marcus, A. Nava, and G. Thiene, Eds., pp. 30-44, Springer, Heidelberg, Germany, 2007.

[101] J. Saffitz, "Cell adhesion pathology," in Arrhythmogenic RV Cardiomyopathy/Dysplasia, F. I. Marcus, A. Nava, and G. Thiene, Eds., Springer, Heidelberg, Germany, 2007.

[102] E. Czarnowska, M. D. Barbera, G. Thiene, M. Valente, and C. Basso, "Ultrastructural substrates," in Arrhythmogenic $R V$ Cardiomyopathy/Dysplasia, F. I. Marcus, A. Nava, and G. Thiene, Eds., pp. 53-60, Springer, Heidelberg, Germany, 2007.

[103] S. Pieperhoff, C. Borrmann, C. Grund, M. Barth, S. Rizzo, and W. W. Franke, "The area composita of adhering junctions connecting heart muscle cells of vertebrates. VII. The different types of lateral junctions between the special cardiomyocytes of the conduction system of ovine and bovine hearts," European Journal of Cell Biology, vol. 89, no. 5, pp. 365-378, 2010.

[104] L.-E. Thornell, A. Eriksson, B. Johansson, and U. Kjorell, "Intermediate filament and associated proteins in heart Purkinje fibers: a membrane-myofibril anchored cytoskeletal system," Annals of the New York Academy of Sciences, vol. 455, pp. 213-240, 1985.
[105] A. Orlandi, H. Hao, A. Ferlosio, et al., "Alpha actin isoforms expression in human and rat adult cardiac conduction system," Differentiation, vol. 77, no. 4, pp. 360-368, 2009.

[106] D. Durrer, R. T. van Dam, G. E. Freud, M. J. Janse, F. L. Meijler, and R. C. Arzbaecher, "Total excitation of the isolated human heart," Circulation, vol. 41, no. 6, pp. 899-912, 1970.

[107] G. Thiene, N. Pennelli, and L. Rossi, "Cardiac conduction system abnormalities as a possible cause of sudden death in young athletes," Human Pathology, vol. 14, no. 8, pp. 707-709, 1983.

[108] H.-P. Kapprell, K. Owaribe, and W. W. Franke, "Identification of a basic protein of Mr 75.000 as an accessory desmosomal plaque protein in stratified and complex epithelia," Journal of Cell Biology, vol. 106, no. 5, pp. 1679-1691, 1988.

[109] H. W. Heid, A. Schmidt, R. Zimbelmann, et al., "Cell type-specific desmosomal plaque proteins of the plakoglobin family: plakophilin 1 (band 6 protein)," Differentiation, vol. 58, no. 2, pp. 113-131, 1995.

[110] A. Schmidt, L. Langbein, M. Rode, S. Prätzel, R. Zimbelmann, and W. W. Franke, "Plakophilins 1a and 1b: widespread nuclear proteins recruited in specific epithelial cells as desmosomal plaque components," Cell and Tissue Research, vol. 290, no. 3, pp. 481-499, 1997.

[111] A. Schmidt, L. Langbein, S. Prätzel, M. Rode, H.-R. Rackwitz, and W. W. Franke, "Plakophilin 3-a novel cell-type-specific desmosomal plaque protein," Differentiation, vol. 64, no. 5, pp. 291-306, 1999.

[112] S. Bonné, J. Van Hengel, F. Nollet, P. Kools, and F. Van Roy, "Plakophilin-3, a novel Armadillo-like protein present in nuclei and desmosomes of epithelial cells," Journal of Cell Science, vol. 161, no. 14, pp. 2265-2276, 1999.

[113] M. Hatzfeld, "Plakophilins: multifunctional proteins or just regulators of desmosomal adhesion?" Biochimica et Biophysica Acta, vol. 1773, no. 1, pp. 69-77, 2007.

[114] C. Mertens, I. Hofmann, Z. Wang, et al., "Nuclear particles containing RNA polymerase III complexes associated with the junctional plaque protein plakophilin 2," Proceedings of the National Academy of Sciences of the United States of America, vol. 98, no. 14, pp. 7795-7800, 2001.

[115] I. Hofmann, M. Casella, M. Schnölzer, T. Schlechter, H. Spring, and W. W. Franke, "Identification of the junctional plaque protein plakophilin 3 in cytoplasmic particles containing RNA-binding proteins and the recruitment of plakophilins 1 and 3 to stress granules," Molecular Biology of the Cell, vol. 17, no. 3, pp. 1388-1398, 2006.

[116] A. Wolf, M. Krause-Gruszczynska, O. Birkenmeier, A. Ostareck-Lederer, S. Hüttelmaier, and M. Hatzfeld, "Plakophilin 1 stimulates translation by promoting eIF4A1 activity," Journal of Cell Biology, vol. 188, no. 4, pp. 463-471, 2010.

[117] W. W. Franke, S. Rickelt, M. Barth, and S. Pieperhoff, "The junctions that don't fit the scheme: special symmetrical cellcell junctions of their own kind," Cell and Tissue Research, vol. 338, no. 1, pp. 1-17, 2009.

[118] S. Rickelt, S. Rizzo, Y. Dörflinger, et al., "A novel kind of tumor type-characteristic junction: Plakophilin-2 as a major protein of adherens junctions in cardiac myxomata," Modern Pathology. In press.

[119] E. Dejana, "Endothelial cell-cell junctions: happy together," Nature Reviews Molecular Cell Biology, vol. 5, no. 4, pp. 261-270, 2004.

[120] M. G. Lampugnani and E. Dejana, "Interendothelial junctions: structure, signalling and functional roles," Current Opinion in Cell Biology, vol. 9, no. 5, pp. 674-682, 1997. 
[121] M. Schmelz and W. W. Franke, "A new type of intercellular junction: desmosomal proteins in the extended junctions of certain endothelial cells of the lymphatic systems," Cell Biology International Reports, vol. 14, p. 54, 1990.

[122] M. Schmelz, R. Moll, C. Kuhn, and W. W. Franke, "Complexus adhaerentes, a new group of desmoplakin-containing junctions in endothelial cells: II. Different types of lymphatic vessels," Differentiation, vol. 57, no. 2, pp. 97-117, 1994.

[123] N. Ebata, Y. Nodasaka, Y. Sawa, et al., "Desmoplakin as a specific marker of lymphatic vessels," Microvascular Research, vol. 61, no. 1, pp. 40-48, 2001.

[124] O. Valiron, V. Chevrier, Y. Usson, F. Breviario, D. Job, and E. Dejana, "Desmoplakin expression and organization at human umbilical vein endothelial cell-to-cell junctions," Journal of Cell Science, vol. 109, no. 8, pp. 2141-2149, 1996.

[125] P. Baluk, J. Fuxe, H. Hashizume, et al., "Functionally specialized junctions between endothelial cells of lymphatic vessels," Journal of Experimental Medicine, vol. 204, no. 10, pp. 2349-2362, 2007.

[126] F. Pfeiffer, V. Kumar, S. Butz, et al., "Distinct molecular composition of blood and lymphatic vascular endothelial cell junctions establishes specific functional barriers within the peripheral lymph node," European Journal of Immunology, vol. 38, no. 8, pp. 2142-2155, 2008.

[127] A. P. Kowalczyk, P. Navarro, E. Dejana, et al., "VEcadherin and desmoplakin are assembled into dermal microvascular endothelial intercellular junctions: a pivotal role for plakoglobin in the recruitment of desmoplakin to intercellular junctions," Journal of Cell Science, vol. 111, no. 20, pp. 3045-3057, 1998.

[128] G. Ian Gallicano, P. Kouklis, C. Bauer, et al., "Desmoplakin is required early in development for assembly of desmosomes and cytoskeletal linkage," Journal of Cell Biology, vol. 143, no. 7, pp. 2009-2022, 1998.

[129] G. I. Gallicano, C. Bauer, and E. Fuchs, "Rescuing desmoplakin function in extra-embryonic ectoderm reveals the importance of this protein in embryonic heart, neuroepithelium, skin and vasculature," Development, vol. 128, no. 6, pp. 929-941, 2001.

[130] G. Jurisic and M. Detmar, "Lymphatic endothelium in health and disease," Cell and Tissue Research, vol. 335, no. 1, pp. 97-108, 2009.

[131] E. Dejana, F. Orsenigo, C. Molendini, P. Baluk, and D. M. McDonald, "Organization and signaling of endothelial cell-to-cell junctions in various regions of the blood and lymphatic vascular trees," Cell and Tissue Research, vol. 335, no. 1, pp. 17-25, 2009.

[132] H. Hennings, D. Michael, and C. Cheng, "Calcium regulation of growth and differentiation of mouse epidermal cells in culture," Cell, vol. 19, no. 1, pp. 245-254, 1980.

[133] H. Hennings and K. A. Holbrook, "Calcium regulation of cell-cell contact and differentiation of epidermal cells in culture. An ultrastructural study," Experimental Cell Research, vol. 143, no. 1, pp. 127-142, 1983.

[134] F. M. Watt, D. L. Mattey, and D. R. Garrod, "Calciuminduced reorganization of desmosomal components in cultured human keratinocytes," Journal of Cell Biology, vol. 99, no. 6, pp. 2211-2215, 1984.

[135] P. Cowin, D. Mattey, and D. Garrod, "Identification of desmosomal surface components (desmocollins) and inhibition of desmosome formation by specific Fab," Journal of Cell Science, vol. 70, pp. 41-60, 1984.
[136] M. P. Demlehner, S. Schäfer, C. Grund, and W. W. Franke, "Continual assembly of half-desmosomal structures in the absence of cell contacts and their frustrated endocytosis:a coordinated sisyphus cycle," Journal of Cell Biology, vol. 131, no. 3, pp. 745-760, 1995.

[137] N. A. Chitaev and S. M. Troyanovsky, "Direct $\mathrm{Ca}^{2+}$ dependent heterophilic interaction between desmosomal cadherins, desmoglein and desmocollin, contributes to cell-cell adhesion adhesion," Journal of Cell Biology, vol. 138, no. 1, pp. 193-201, 1997.

[138] J. Koeser, S. M. Troyanovsky, C. Grund, and W. W. Franke, "De novo formation of desmosomes in cultured cells upon transfection of genes encoding specific desmosomal components," Experimental Cell Research, vol. 285, no. 1, pp. 114-130, 2003.

[139] C. J. Schmitt, W. W. Franke, S. Goerdt, B. Falkowska-Hansen, S. Rickelt, and W. K. Peitsch, "Homo- and heterotypic cell contacts in malignant melanoma cells and desmoglein 2 as a novel solitary surface glycoprotein," Journal of Investigative Dermatology, vol. 127, no. 9, pp. 2191-2206, 2007.

[140] S. Rickelt, W. W. Franke, Y. Doerflinger, S. Goerdt, J. M. Brandner, and W. K. Peitsch, "Subtypes of melanocytes and melanoma cells distinguished by their intercellular contacts: heterotypic adherens junctions, adhesive associations, and dispersed desmoglein 2 glycoproteins," Cell and Tissue Research, vol. 334, no. 3, pp. 401-422, 2008. 


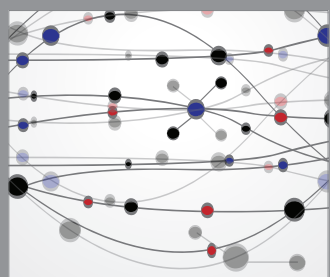

The Scientific World Journal
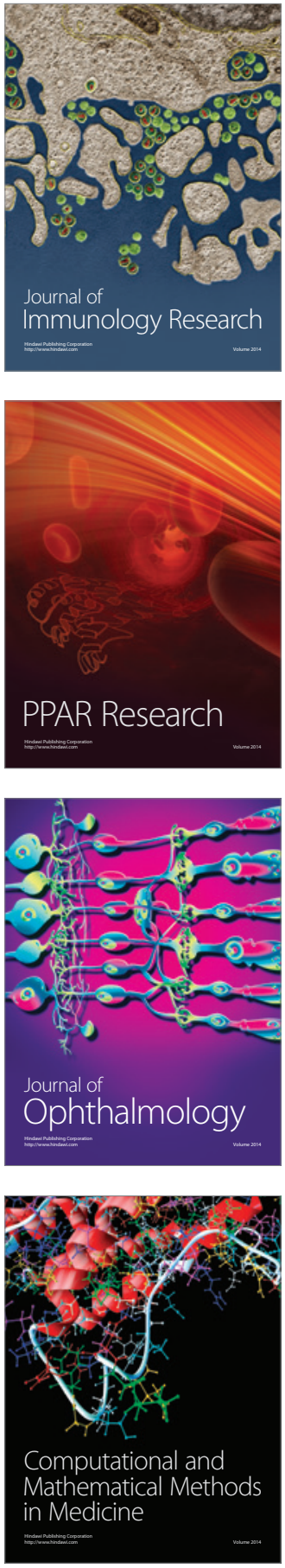

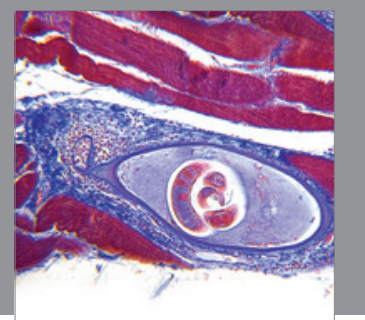

Gastroenterology

Research and Practice
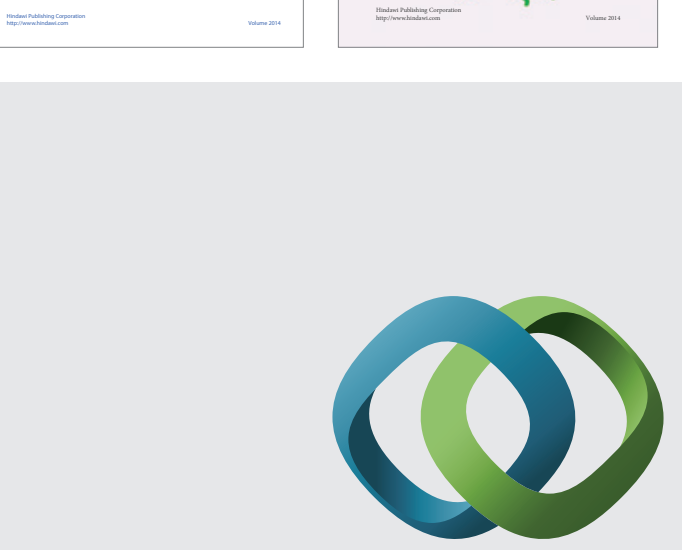

\section{Hindawi}

Submit your manuscripts at

http://www.hindawi.com
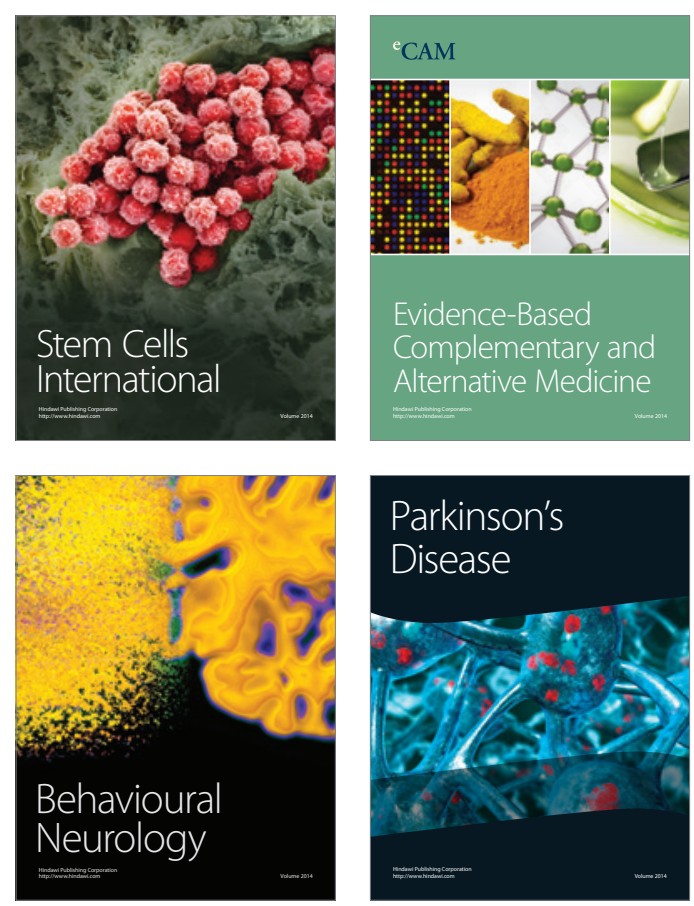

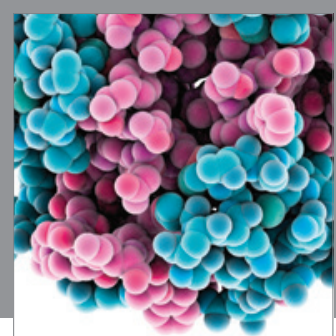

Journal of
Diabetes Research

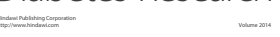

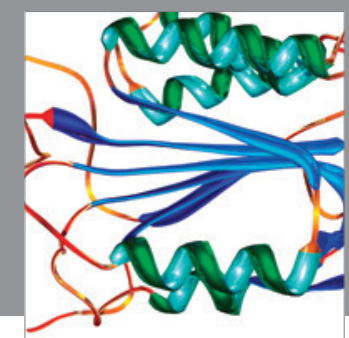

Disease Markers
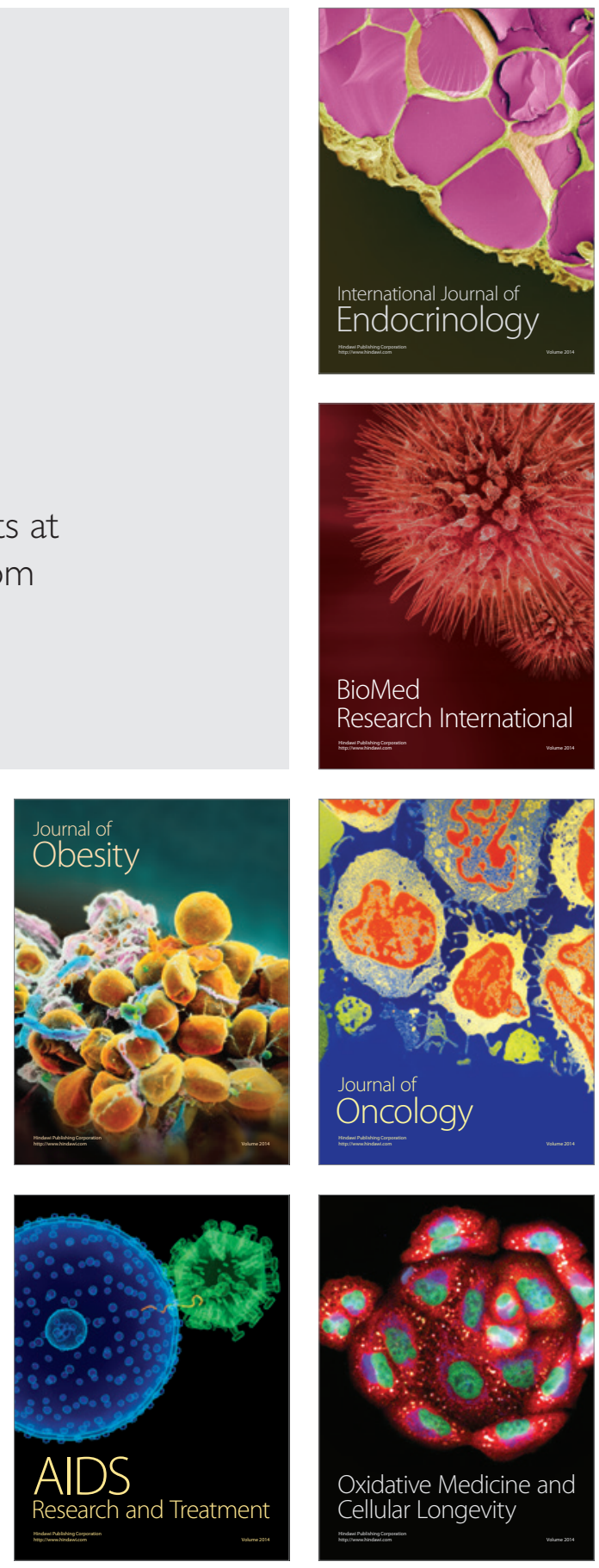